\title{
Investigation of Depression and Anxiety in Students due to Burdenized Curriculum and Shortage of Time at University level
}

\author{
Dr. Fozia Fatima ${ }^{1}$, Saima Naz $^{2}$, Dr. Nadia Shabnam ${ }^{1}$, Dr. Sabir Ali ${ }^{3}$, Sobia Fatima ${ }^{4}$
}

\begin{abstract}
This study was undertaken to investigate depression and anxiety in students due to burdenized curriculum and shortage of time at university level. This study was descriptive in nature. 260 students were taken as a sample and it was drawn from three public universities of Islamabad through random sampling technique. Self-developed questionnaire was used and its reliability and validity had been estimated by Cronbach alpha and exploratory factor analysis respectively. Results of this study showed that majority of the students were agreed that they had depression and anxiety due to burdenized curriculum and shortage of time. They were not able to learn necessary skills that enhance their performance. Most of the students generally expressed anxiety when they were insulted by their parents and peers due to the bad performance in academics. Demographic factors (gender, age \& qualification) had no significant effect over the students' perception about their depression and anxiety at university level.
\end{abstract}

Keywords: Burdenized Curriculum, Depression and Anxiety, Descriptive Design, Shortage of time, University students

Received: 12 March 2021; Revised

Received: 18 June 2021; Accepted: 23 June 2021

${ }^{1}$ Assistant Professor, Department of Health Professions Education, National University of Medical Sciences, Rawalpindi, Pakistan ${ }^{2}$ Department of Education, Faculty of Social Sciences, International Islamic University, Islamabad, Pakistan

${ }^{3}$ Head of Department, Department of Educational Development, University of Baltistan, Sakrdu, Gilgit Baltistan, Pakistan ${ }^{4}$ Legal Officer, National University of Medical Sciences, Rawalpindi, Pakistan

\section{Corresponding Author Email:}

nadiakhan.qau@gmail.com

\section{Introduction}

People now understand stress as a lifestyle crisis, which affects all individuals regardless of their stage of development. Parents' expectations about their children have become a heavy burden on students. These children can no longer bear these burdens, and students feel depressed, tired and anxious on many issues. Depression and anxiety are major problems for students both in developed and developing countries. Depression has also been found in adolescents because it is related to inattention, fear of failure and negative evaluation of the future. Pakistani educational system also plays a catalytic role in increasing the stress level of students. Parents and institutions relentlessly instilled a fear of failure, and this fear affected their self-esteem and confidence. Depression is the leading cause of morbidity worldwide (Fatima, 2019). Nobody seems to be able to get rid of this empty horror. The rapid growth of Pakistani population and its major role in current global events underscores the need to create an evidence base to guide future policies and implement new strategies to combat depression.

Depression and anxiety refer to abnormal changes in the mood of a group of people.

This article is distributed under the terms of the Creative Commons Attribution Non Commercial 4.0 License (http://www.creativecommons.org/licenses/by-nc/4.0/) which permits nonCommercial use, reproduction and distribution of the work without further permission provided the original work is attributed as specified. 
These conditions are the result of chemical reactions in the brain. $90 \%$ of people with anxiety disorders will suffer from depression as well (Fatima et al., 2018). People with depression and anxiety disorders often exhibit inner feelings, loss of pleasure or interest, low self-esteem and anorexia (Fatima et al., 2018). Some people face depression due to financial problems and parental adjustment (Fatima, 2017). Pakistani youth face depression and anxiety because of unemployment (Masih \& Gulrez, 2006). The causes of depression include complex interactions between social, psychological, and biological factors (Fatima \& Ali, 2016). There was no difference between depression and anxiety, but there were some factors that distinguish them. It had been suggested that loneliness can be used as a useful factor in distinguishing anxious students from depressed students and that depressed students tend to report more feelings of loneliness (Ali \& Fatima, 2016). Since everything had its pros and cons, a small amount of anxiety was good for studies like facilitative anxiety. It was a relatively manageable degree of stress associated with school conditions, which leads to motivation and motivation to support optimum performance (Ali \& Fatima, 2015). However, when the level of stress surpasses the managing policies attainable by the student, the stress of the situation could overcome the control of the event and make them helpless (Khanna \& Khanna, 1990).

As earlier explained, students become more anxious and depressed due to burdenized curriculum. In present scenario, curriculum was too much tough and challenging and does not according to student mental level. Due to these reasons, students become patient of anxiety and depression. Most researches had shown that as the students were expected to be well prepared for future needs, so they had increased level of anxiety and depression. The university students were facing anxiety and depression more than others in all over the world. Fear of interaction, self-awareness, denial of inferiority, shame, and frustration cause people to avoid participating in activities that involved all types of people. Depression and anxiety became the most common illnesses of our society and community that affect the people mentally as well as physically (Bashir, 2016). Most of the symptoms faced by the patients of anxiety were similar to the symptoms faced by the patient of depression (Fatima \& Ali, 2019). Depression and anxiety in the high school and college students had serious negative academic result as well as psychological effects. Symptoms of depression include nap difficulty, weight change, increased suicidal thoughts, and therefore, increased learning difficulties (Sohail, 2013). Depression and anxiety were not good for learners but became dangerous if the learners were suffering from both of them as it lowers the level of psychological health. Longer the duration of symptoms, the longer was the treatment period as well. Similarly, the longer the suicide attempt, the higher the incidence rate (Ali \& Fatima, 2016).

This article focuses on the theory of Paul Ratanasiripong (2012). University students face many challenges including shortage of time and burden of curriculum which leads to depression and anxiety. Therefore, our area of study is that anxiety and depression is produced because of burdenized curriculum and shortage of time (Figure 1). The target population is comprised of the university students in Islamabad. The routine becomes hectic and burdened now a day for all the level of learners but specifically the university students are the main or central victim of this suffering and calamity. As they take classes from morning till evening which becomes two times of the normal learning time of students at the college or school level. Shortage of time in the semester system 
coupled with the other activities including assignments, quiz, and presentations becomes an addition in enhancing or developing depression \& anxiety in the students. Students show inappropriate academic performance because they are suffering from anxiety and depression due to the burdened curriculum and shortage of time. The purpose of this study is to investigate the depression and anxiety faced by students due to burdenized curriculum and shortage of time at university level.
Moreover, it also aimed at examining the effect of demographic factors such as gender, age, and qualification. This study has the following objectives:

1. To determine the perception of students about the depression and anxiety at university level.

2. To explore the effect of demographic factors over the perceptions of students about depression \& anxiety at university level.

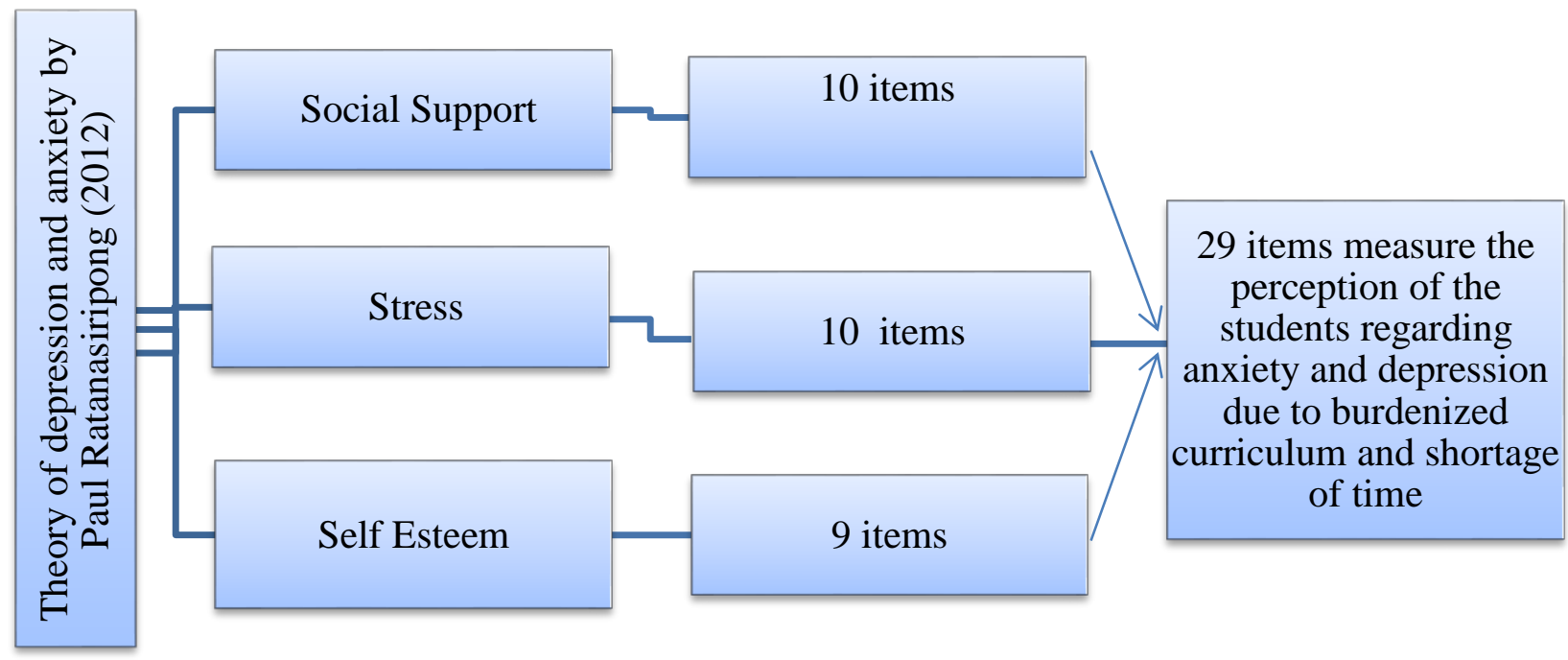

Figure 1

Conceptual Framework of the Study

\section{Method}

\section{Research Design}

This study was quantitative in nature. Descriptive and cross sectional design was used by survey method.

\section{Population \& Sample}

International Islamic University Islamabad, Arid Agricultural University Islamabad and National University of Modern languages Islamabad students were considered as targeted population of this study due to the delimitation of public sector universities. These universities were targeted because they offered both undergraduate (BS) and postgraduate programs (MA, MPhil) of "Education Subject". This study was delimited to Social Science discipline and from this discipline, only education subject was targeted. Bachelor, MA, and M.Phil scholars of International Islamic University Islamabad (1530), Arid Agricultural University of Islamabad (895), and National University of Modern Language (2094) were considered population of this study. 300 questionnaires were distributed among the sample through random sampling technique. 260 university students returned the filled questionnaires and were included in the final analysis. $86.6 \%$ was the response rate because researchers themselves went to respective universities and clearly demonstrated the importance of this study and personally collected their questionnaires from the desired sample. The characteristics 
of population and response rate are given

below (Table 1).

Table 1

Population Characteristics and Distribution of Sample

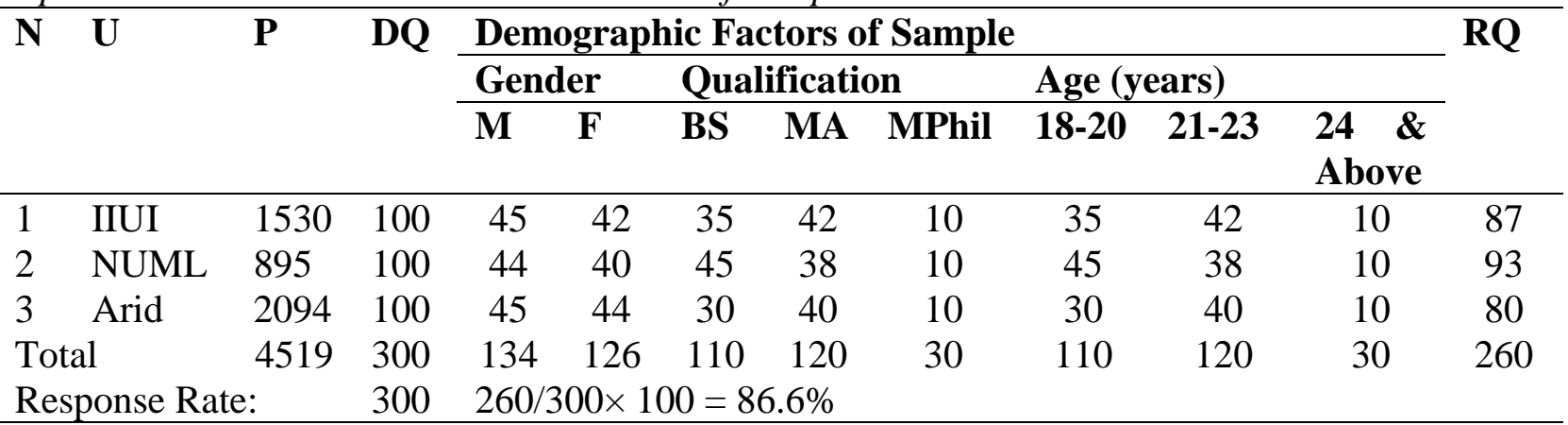

Note. $*$ IIUI= International Islamic University Islamabad, NUML= National University of Modern Languages, Arid= Arid Agriculture University, $\mathrm{U}=$ Universities, $\mathrm{P}=$ Population, $\mathrm{DQ}=$ Distributed Questionnaires, RQ= Returned Questionnaire)

\section{Measures}

A self-developed questionnaire used that was based on the theory of depression and anxiety by Paul Ratanasiripong in June 2012. This questionnaire was developed by keeping in mind the objective of this study. It was consisting of twenty-nine items that had been finalized after exploratory factor analysis. The content validity of self-developed questionnaire was checked by the experts of social sciences who belonged to International Islamic university Islamabad. They checked the phraseology and language of the instrument. Construct validity was measured through exploratory factor analysis. Reliability of self-developed questionnaire was checked by Cronbach alpha method (Fatima, 2016). Validity and reliability of this questionnaire were measured through pilot testing. For this purpose, researchers firstly distributed 25 questionnaires among sample that was not included into final data analysis. These 25 filled questionnaires were only used for validity and reliability checking before its final administration.

Table 2

Exploratory Factor Analysis $(N=260)$

\begin{tabular}{lccccc}
\hline \multicolumn{1}{c}{ Descriptive Statistics } & \multicolumn{2}{c}{ Communalities } \\
\hline \multicolumn{1}{c}{ Items } & Mean & $\begin{array}{c}\text { Std. } \\
\text { Deviation }\end{array}$ & N & Initial & Extraction \\
\hline $\begin{array}{l}\text { I feel depressed due to } \\
\text { social involvement. }\end{array}$ & 3.38 & .65 & 25 & 1.00 & .62 \\
$\begin{array}{l}\text { I feel failure in academic } \\
\text { performance due to } \\
\text { burdenized curriculum. }\end{array}$ & 3.40 & .68 & 25 & 1.00 & .73 \\
$\begin{array}{l}\text { I feel depressed due to } \\
\text { meet the high expectation } \\
\text { of teachers under } \\
\text { shortage of time. }\end{array}$ & 2.85 & & & & \\
\hline
\end{tabular}




\begin{tabular}{|c|c|c|c|c|c|}
\hline $\begin{array}{l}\text { I feel neurosis due to high } \\
\text { expectations of parents } \\
\text { regarding my academic } \\
\text { performance. }\end{array}$ & 2.41 & 1.15 & 25 & 1.00 & .67 \\
\hline $\begin{array}{l}\text { I feel insulted when I } \\
\text { didn't come up with my } \\
\text { parental expectation due } \\
\text { to burdened curriculum. }\end{array}$ & 2.16 & 1.07 & 25 & 1.00 & .61 \\
\hline $\begin{array}{l}\text { I feel insult by my peers } \\
\text { due to the bad } \\
\text { performance in } \\
\text { academics. }\end{array}$ & 2.35 & 1.07 & 25 & 1.00 & .58 \\
\hline $\begin{array}{l}\text { I am becoming a victim } \\
\text { of stress due to } \\
\text { excessive/extreme } \\
\text { curriculum. }\end{array}$ & 2.93 & 1.06 & 25 & 1.00 & .62 \\
\hline $\begin{array}{l}\text { I am not happy with } \\
\text { semester schedule. }\end{array}$ & 2.37 & 1.19 & 25 & 1.00 & .55 \\
\hline $\begin{array}{l}\text { I am not able to become a } \\
\text { good student with my } \\
\text { mental disorders }\end{array}$ & 3.12 & .86 & 25 & 1.00 & .60 \\
\hline $\begin{array}{l}\text { I feel that excessive } \\
\text { curriculum is becoming a } \\
\text { hurdle in my successes }\end{array}$ & 3.15 & .91 & 25 & 1.00 & .58 \\
\hline $\begin{array}{l}\text { I feel difficulty in } \\
\text { managing my daily life } \\
\text { activities due to excessive } \\
\text { study hours. }\end{array}$ & 3.76 & .64 & 25 & 1.00 & .65 \\
\hline $\begin{array}{l}\text { I feel depressed because } \\
\text { no one understands the } \\
\text { difficult situation due to } \\
\text { which grade is affected. }\end{array}$ & 3.68 & .88 & 25 & 1.00 & .63 \\
\hline $\begin{array}{l}\text { I feel depressed and show } \\
\text { lack of interests in the } \\
\text { study due to excessive } \\
\text { semester syllabus. }\end{array}$ & 3.24 & .77 & 25 & 1.00 & .65 \\
\hline $\begin{array}{l}\text { I ever try to commit } \\
\text { suicide due to burdened } \\
\text { of curriculum, Shortage } \\
\text { of time and parental } \\
\text { pressure for good } \\
\text { performance in exam. }\end{array}$ & 3.36 & .84 & 25 & 1.00 & .65 \\
\hline $\begin{array}{l}\text { I ever experienced that } \\
\text { depression and anxiety } \\
\text { affect my physical health } \\
\text { and cause lower appetite. }\end{array}$ & 3.88 & 2.61 & 25 & 1.00 & 60 \\
\hline
\end{tabular}




\begin{tabular}{|c|c|c|c|c|c|}
\hline $\begin{array}{l}\text { I faced disturb sleep } \\
\text { schedules due to the } \\
\text { burdened curriculum and } \\
\text { shortage of time during } \\
\text { semester series. }\end{array}$ & 3.78 & .68 & 25 & 1.00 & .73 \\
\hline $\begin{array}{l}\text { I feel anxiety neurosis } \\
\text { and useless due to } \\
\text { favoritism system in the } \\
\text { class. }\end{array}$ & 3.33 & .99 & 25 & 1.00 & .64 \\
\hline $\begin{array}{l}\text { I experienced blood } \\
\text { pressure }(\mathrm{BP}) \text { problem } \\
\text { due to depression. }\end{array}$ & 3.79 & .68 & 25 & 1.00 & .74 \\
\hline $\begin{array}{l}\text { I feel negative vibes due } \\
\text { to critical semester exam } \\
\text { system. }\end{array}$ & 3.58 & .86 & 25 & 1.00 & .69 \\
\hline $\begin{array}{l}\text { I feel anxiety and } \\
\text { depression is the major } \\
\text { hindrance in mental } \\
\text { health and well-being of } \\
\text { universities students. }\end{array}$ & 3.72 & .75 & 25 & 1.00 & .63 \\
\hline $\begin{array}{l}\text { I ever face anxiety } \\
\text { neurosis due to worry } \\
\text { over test failure and lower } \\
\text { test memory. }\end{array}$ & 3.61 & .75 & 25 & 1.00 & .62 \\
\hline $\begin{array}{l}\text { I am not able to take a } \\
\text { part in co-curricular } \\
\text { activities due to the } \\
\text { burdenized curriculum. }\end{array}$ & 3.82 & .59 & 25 & 1.00 & .56 \\
\hline $\begin{array}{l}\text { I feel depression because } \\
\text { I am not able to go } \\
\text { anywhere due to work } \\
\text { load. }\end{array}$ & 3.70 & .75 & 25 & 1.00 & .68 \\
\hline $\begin{array}{l}1 \text { ever shows arrogance } \\
\text { due to burdened } \\
\text { curriculum and anxiety } \\
\text { neurosis. }\end{array}$ & 3.70 & .74 & 25 & 1.00 & .70 \\
\hline $\begin{array}{l}\text { Sometime I am not able } \\
\text { to tolerate situation due to } \\
\text { word load and shortage of } \\
\text { time. }\end{array}$ & 3.61 & .75 & 25 & 1.00 & .57 \\
\hline $\begin{array}{l}\text { I faced several hurdles in } \\
\text { university due to the } \\
\text { burdenized curriculum } \\
\text { and shortage of time. }\end{array}$ & 3.58 & .63 & 25 & 1.00 & .71 \\
\hline
\end{tabular}




\begin{tabular}{|c|c|c|c|c|c|}
\hline $\begin{array}{l}\text { I feel that my } \\
\text { performance is also } \\
\text { affected due to anxiety } \\
\text { and tension of others } \\
\text { subjects. }\end{array}$ & 3.57 & .80 & 25 & 1.00 & .61 \\
\hline $\begin{array}{l}\text { Sometime I miss-behave } \\
\text { due to depression and } \\
\text { excessive workload. }\end{array}$ & 3.81 & .62 & 25 & 1.00 & .63 \\
\hline $\begin{array}{l}\text { I am not able to learn } \\
\text { necessary skills that } \\
\text { enhance my performance } \\
\text { due to work load. }\end{array}$ & 3.64 & .87 & 25 & 1.00 & .65 \\
\hline
\end{tabular}

Extraction method during exploratory factor analysis shows that items related to depression and anxiety were valid and reliable. The whole analysis is summarized in Table 2.

\section{Table 3}

Reliability of the Scale $(N=260)$

\begin{tabular}{lllll}
\hline Sr.No & Variable & No. of items & $\begin{array}{l}\text { Cronbach } \\
\text { Value }\end{array}$ & Alpha \\
\hline 1. & Depression and anxiety & 29 & .88 & \\
\hline
\end{tabular}

Table 3 shows that all items related to depression and anxiety were reliable and valid for final administration. The Cronbach alpha reliability of the self developed scale was .88 .

\section{Results}

\section{Table 4}

Percentage Responses of Participants regarding Depression and Anxiety of the students due to burdenized Curriculum and Shortage of Time at university level $(N=260)$

\begin{tabular}{llllllll}
\hline No & Items & SDA & DA & N & A & SA & Mean \\
\hline 1 & $\begin{array}{l}\text { I feel depressed } \\
\text { due to social } \\
\text { involvement. }\end{array}$ & $10.9 \%$ & $17.2 \%$ & $20.6 \%$ & $30.7 \%$ & $18.0 \%$ & 3.28 \\
2 & $\begin{array}{l}\text { I feel failure in 7.5\% } \\
\text { academic } \\
\text { performance due } \\
\text { to burdenized } \\
\text { curriculum. }\end{array}$ & $15.4 \%$ & $16.5 \%$ & $22.1 \%$ & $36.0 \%$ & 3.65 \\
3 & $\begin{array}{l}\text { I feel depressed 10.9\% } \\
\text { due to meet the } \\
\text { high expectation }\end{array}$ & $14.2 \%$ & $25.8 \%$ & $27.7 \%$ & $18.7 \%$ & 3.30 \\
\hline
\end{tabular}




\begin{tabular}{|c|c|c|c|c|c|c|c|}
\hline & of teachers under & & & & & & \\
\hline 4 & $\begin{array}{l}\text { I feel neurosis due } \\
\text { to high } \\
\text { expectations of } \\
\text { parents regarding } \\
\text { my academic } \\
\text { performance. }\end{array}$ & $7.5 \%$ & $32.2 \%$ & $15.4 \%$ & $21.0 \%$ & $21.3 \%$ & 3.16 \\
\hline 5 & $\begin{array}{l}\text { I feel insulted } \\
\text { when I didn't } \\
\text { come up with my } \\
\text { parental } \\
\text { expectation due to } \\
\text { burdened } \\
\text { curriculum. }\end{array}$ & $9.7 \%$ & $11.6 \%$ & $16.9 \%$ & $25.1 \%$ & $34.1 \%$ & 3.63 \\
\hline 6 & $\begin{array}{l}\text { I feel insult by my } \\
\text { peers due to the } \\
\text { bad performance } \\
\text { in academics. }\end{array}$ & $12.0 \%$ & $13.9 \%$ & $12.4 \%$ & $21.7 \%$ & $37.5 \%$ & 3.60 \\
\hline 7 & $\begin{array}{l}\text { I am becoming a } \\
\text { victim of stress } \\
\text { due }\end{array}$ & $9.4 \%$ & $16.9 \%$ & $25.1 \%$ & $31.8 \%$ & $14.2 \%$ & 3.25 \\
\hline & $\begin{array}{l}\text { excessive/extreme } \\
\text { curriculum. }\end{array}$ & & & & & & \\
\hline 8 & $\begin{array}{l}\text { I am not happy } \\
\text { with semester } \\
\text { schedule. }\end{array}$ & $13.9 \%$ & $18.0 \%$ & $21.7 \%$ & $24.7 \%$ & $19.1 \%$ & 3.17 \\
\hline 9 & $\begin{array}{l}\text { I am not able to } \\
\text { become a good } \\
\text { student with my } \\
\text { mental disorders }\end{array}$ & $12.4 \%$ & $18.0 \%$ & $22.8 \%$ & $22.5 \%$ & $21.7 \%$ & 3.23 \\
\hline 10 & $\begin{array}{l}\text { I feel that } \\
\text { excessive } \\
\text { curriculum is } \\
\text { becoming a hurdle } \\
\text { in my successes }\end{array}$ & $16.1 \%$ & $11.2 \%$ & $15.0 \%$ & $22.1 \%$ & $33.0 \%$ & 3.45 \\
\hline 11 & $\begin{array}{l}\text { I feel difficulty in } \\
\text { managing my } \\
\text { daily life activities } \\
\text { due to excessive } \\
\text { study hours. }\end{array}$ & $13.5 \%$ & $9.0 \%$ & $17.6 \%$ & $23.2 \%$ & $34.1 \%$ & 3.56 \\
\hline 12 & $\begin{array}{l}\text { I feel depressed } \\
\text { because no one } \\
\text { understands the } \\
\text { difficult situation }\end{array}$ & $8.2 \%$ & $15.4 \%$ & $20.6 \%$ & $24.7 \%$ & $28.5 \%$ & 3.51 \\
\hline
\end{tabular}




\begin{tabular}{|c|c|c|c|c|c|c|c|}
\hline & $\begin{array}{l}\text { due to which } \\
\text { grade is affected. }\end{array}$ & & & & & & \\
\hline 13 & $\begin{array}{l}\text { I feel depressed } \\
\text { and show lack of } \\
\text { interests in the } \\
\text { study due to } \\
\text { excessive } \\
\text { semester syllabus. }\end{array}$ & $25.1 \%$ & $16.9 \%$ & $16.5 \%$ & $13.9 \%$ & $25.1 \%$ & 2.96 \\
\hline 14 & $\begin{array}{l}\text { I ever try to } \\
\text { commit suicide } \\
\text { due to burdened } \\
\text { of curriculum, } \\
\text { Shortage of time } \\
\text { and parental } \\
\text { pressure for good } \\
\text { performance in } \\
\text { exam. }\end{array}$ & $22.8 \%$ & $17.2 \%$ & $15.0 \%$ & $19.9 \%$ & $22.5 \%$ & 3.01 \\
\hline 15 & $\begin{array}{l}\text { I ever experienced } \\
\text { that depression } \\
\text { and anxiety affect } \\
\text { my physical } \\
\text { health and cause } \\
\text { lower appetite. }\end{array}$ & $7.9 \%$ & $10.9 \%$ & $18.7 \%$ & $34.5 \%$ & $25.5 \%$ & 3.60 \\
\hline 16 & $\begin{array}{l}\text { I faced disturb } \\
\text { sleep schedules } \\
\text { due to the } \\
\text { burdened } \\
\text { curriculum and } \\
\text { shortage of time } \\
\text { during semester } \\
\text { series. }\end{array}$ & $16.9 \%$ & $10.9 \%$ & $16.5 \%$ & $18.4 \%$ & $34.8 \%$ & 3.44 \\
\hline 17 & $\begin{array}{l}\text { I feel anxiety } \\
\text { neurosis and } \\
\text { useless due to } \\
\text { favoritism system } \\
\text { in the class. }\end{array}$ & $10.5 \%$ & $18.4 \%$ & $22.1 \%$ & $24.0 \%$ & $22.5 \%$ & 3.30 \\
\hline 18 & $\begin{array}{l}\text { I experienced } \\
\text { blood pressure } \\
\text { (BP) problem due } \\
\text { to depression. }\end{array}$ & $10.1 \%$ & $17.6 \%$ & $22.1 \%$ & $25.1 \%$ & $22.5 \%$ & 3.33 \\
\hline 19 & $\begin{array}{l}\text { I feel negative } \\
\text { vibes due to } \\
\text { critical semester } \\
\text { exam system. }\end{array}$ & $6.4 \%$ & $17.6 \%$ & $18.4 \%$ & $36.3 \%$ & $18.7 \%$ & 3.44 \\
\hline 20 & $\begin{array}{l}\text { I feel anxiety and } \\
\text { depression is the }\end{array}$ & $7.5 \%$ & $12.7 \%$ & $21.3 \%$ & $26.6 \%$ & $29.2 \%$ & 3.58 \\
\hline
\end{tabular}




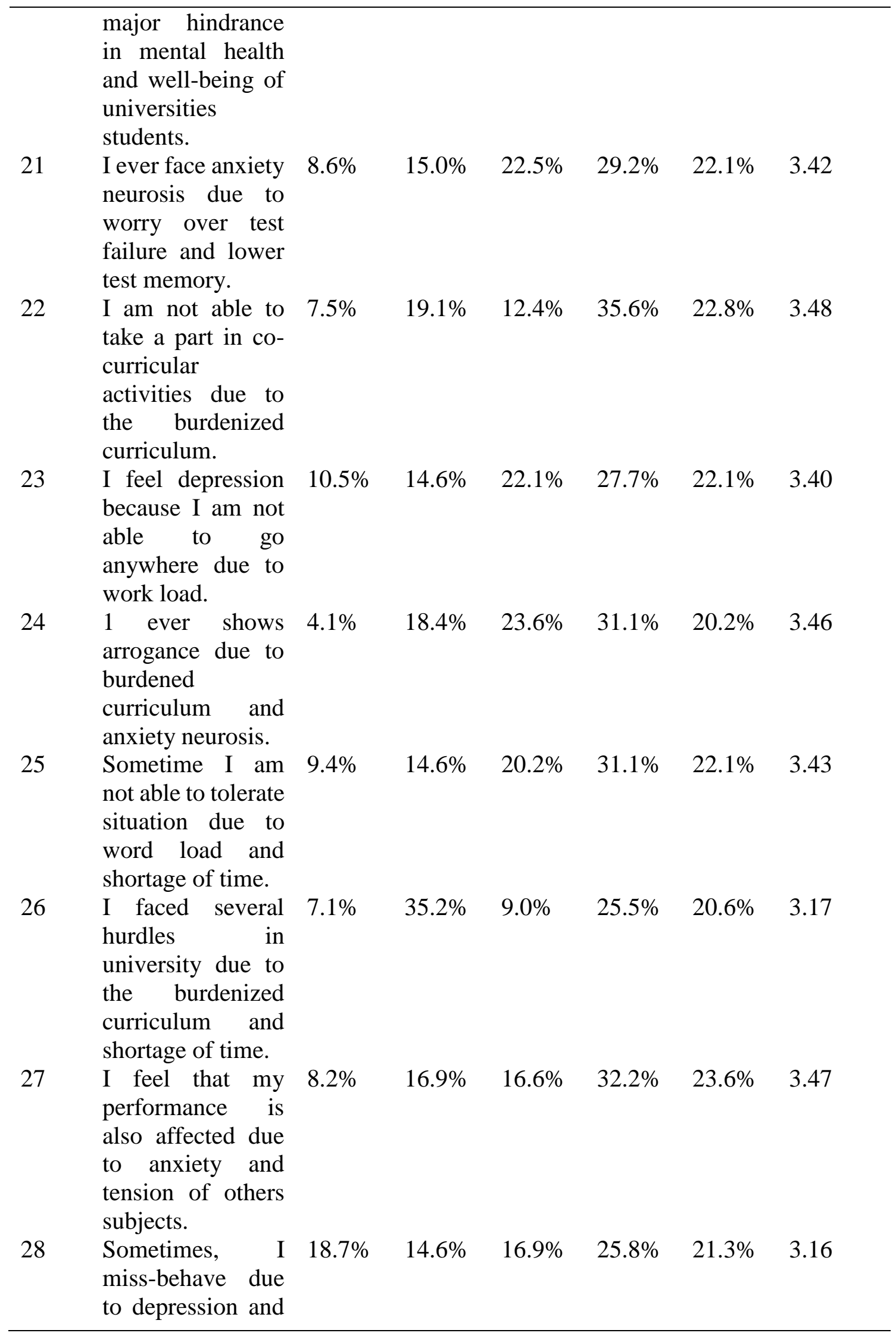


excessive

workload.
I am not able to
learn necessary
skills that enhance
my performance
due to work load.

The Table 4 shows that majority of the participants were depressed due to social involvement (30.7\%). They felt failure in academic performance due to burdenized curriculum $(36.0 \%)$. They were not able to meet the high expectation of teachers due to shortage of time $(27.7 \%)$. They felt anxiety neurosis due to high expectations of parents regarding their academic performance (32.2\%). They felt insulted when they did not come up with their parental expectation due to burdened curriculum (34.1\%). Students were depressed and showed anxiety whenever they were insulted by their peers due to the bad performance in academics (37.5\%); they were becoming a victim of stress due to excessive/extreme curriculum(31.8\%); they were not happy with semester schedule ( $24.7 \%$ ); they were not agreed that they were able to become a good teacher with mental disorders $(22.8 \%)$; they felt excessive curriculum was becoming a hurdle in their success $(33.0 \%)$; they felt difficulty in managing their daily life activities due to excessive study hours (34.1\%); they felt depressed because no one understood their difficult situation due to which their grades were affected (28.5\%); they felt depressed and had low self-worth and had lack of interests in their study due to excessive semester syllabus(25.1\%); they tried to commit suicide due to burden of curriculum, shortage of time and parental pressure for good performance in exams $(22.8 \%)$. They experienced that depression and anxiety affected their physical health and caused lower appetite (34.5\%); they faced disturbed sleep schedules due to the burdened curriculum and shortage of time during the semester ( $34.8 \%$ ); they felt anxiety neurosis and felt useless due to favoritism system in the class (24.0\%); they felt anxiety and depression was the major hindrance in mental health and well-being of university students (29.2\%). They faced anxiety neurosis due to worry over test failure and lowered test memory $(29.2 \%)$. They were not able to take part in co-curricular activities due to the burdenized curriculum (35.6\%). They felt depression during semester, not being able to go anywhere due to work load $(27.7 \%)$. They showed arrogance due to burdenized curriculum and anxiety neurosis (31.1\%). Sometimes, they were not able to tolerate things due to work load and shortage of time $(31.1 \%)$. They faced several hurdles in university due to burdenized curriculum and shortage of time $(35.2 \%)$. They felt that their performance was also affected due to anxiety and tension of others subjects (32.2\%). Sometimes, they miss-behaved due to depression and excessive workload (25.8 \%). They were not able to learn necessary skills that enhance their performance due to work load $(34.5 \%)$. 
Table 5

t-test for Gender differences in Depression and Anxiety $(N=260)$

\begin{tabular}{llcccccc}
\hline Variable & Gender & N & M & SD & df & t-value & Sig \\
\hline & & & & & & & \\
Depression & Male & 134 & 97.05 & 20.88 & 258 & -1.09 & .27 \\
Anxiety & Female & 126 & 99.54 & 15.18 & & & \\
\hline
\end{tabular}

Table 5 shows that the mean value of Male $(\mathrm{M}=97.05)$ and the mean value of female is $(M=99.54)$. It means that the difference between mean value is $(p=.27)$ which is not statistically significant. The students had no significant gender difference regarding their depression and anxiety at university level.

Table 6

Analysis of Variance (ANOVA) for Impact of Age and Qualification $(N=260)$

\begin{tabular}{llccll}
\hline Age & $\begin{array}{l}\text { Sum } \\
\text { Squares }\end{array}$ & of df & Mean Square & F & Sig. \\
\hline Between Groups & 287.19 & 2 & 143.59 & .42 & .65 \\
Within Groups & 86967.49 & 257 & 338.39 & & \\
Qualification & & & & & \\
Between Groups & 889.70 & 2 & 444.85 & 1.32 & .26 \\
Within Groups & 86364.98 & 257 & 336.05 & & \\
\hline
\end{tabular}

The Table 6 shows the mean square of between age groups $(M=143.59)$ and within age groups $(\mathrm{M}=253.65)$ regarding depression and anxiety due to burdenized curriculum and shortage of time at university level. However, the difference in mean was not significant $(p=.65)$. The Table 6 also shows the mean square of between qualification groups $(M=444.85)$ and within qualification

\section{Discussion}

It was found that students mostly faced depression and anxiety due to the burdenized curriculum and shortage of time during semester system. This result is quite similar to the work of Smith et al. (2007) who found that depression and anxiety was serious mental disorders facing by university students. These disorders not only affect the groups ( $M=336.05)$ regarding depression and anxiety due to burdnize curriculum and shortage of time at university level. However, the difference in mean was not significant $(p=.26)$. Hence, age and qualification had no significant effect on the perception of students regarding their depression and anxiety at university level.

mental health of the students but also had great impact on the students' physical health. It was also found that anxiety and depression had negative impact on the academic performance of the respondent which led to different critical issues such as frustration etc. Mean values showed that bulks of the contributors were approved that they were not capable to learn. Similarly, there were not 
able to learn necessary skills that enhance their performance due to work load and highly agreed with that they felt failure in academic performance due to burdenized curriculum. These findings were closely related with the results of Reddy et al. (2018); Deb (2015), and Ang and Huan (2006) works. Majority of respondents were agreed with that they felt insulted when they did not come up with their parental expectation due to burdenized curriculum and they also experienced depression and anxiety that affected their physical health and caused lower appetite and even they were also insulted by their peers due to the bad performance in academics. This result is also similar with the work of Bashir (2016) and Shah (2017). It was also found that participants were strongly agreed that they

\section{Conclusion}

The study concluded that majority of the students were agreed that they had depression and anxiety problem due to burdenized curriculum and shortage of time. They were not able to learn necessary skills that enhance their performance due to work load. Most of the students generally expressed depression

\section{Limitations}

The present study did not involve the assessment of social support and self esteem as an outcome in response to burdenized curriculum at university level. Moreover, the present study was limited in its generalizability as the data was only obtained from universities located in Islamabad. The Recommendations

On the basis of conclusions, following recommendations had been made:

1. Teacher must pay attention to the students and diagnose the reason behind the poor learning outcomes and poor academic achievement of the students. The teachers should also consult the parents and asked them not to set high expectations from their felt anxiety and depression were the major hindrance in psychological fitness as well as comfort of university pupils and they felt difficulty in managing their daily life activities due to excessive study hours, also they felt depressed because no one understood their difficult situation due to which grade was affected. This finding was supported by the work of several researchers such as Fatima and Ali (2020); Khanna and Khanna, 1990; Deb (2015) and Dobson (2012). Similarly, inferential statistic showed that demographic factors had no significant effect over the students perception about their depression and anxiety at university level and this finding was quite similar with the work of Ali et al. (2018), Fatima (2014), Ali and Fatima (2016) and Busari (2012).

and anxiety when they were insulted by their parents and peers due to the bad performance in academics. Demographic factors (gender, age $\&$ qualification) had no significant effect over the perception of the learners about their depression and anxiety at university level.

data from other cities would make the results more generalizable. Similarly, future studies may be conducted with other demographic variables such as birth order to get a view of impact of those variables on students depression and anxiety due to burdenized curriculum.

children because they were not able to cope up with the lengthy curriculum which may ultimately lead to anxiety and depression.

2. The government should instruct the curriculum developers that the curriculum was not so burdenized and lengthy. Only necessary concepts and details should be added. 
3. The learning hours should be according to the maximum capacity of the learners because long learning hours directly caused depression and anxiety.

4. Teachers should also have paid attention to the phenomenon of individual differences while

\section{Conflict of Interest}

There is no conflict of interest among authors.

\section{References}

Ali, S., \& Fatima, F. (2015). Comparative Study of Public and Private Educational Institutes towards the Recruitment, Retention and Reward of Their Teachers. Journal of literature, languages and linguistics, An international Peer-Reviewed journal, 14(2), 51-56.

Ali, S., \& Fatima, F. (2016). Teachers' insights about the eminence of performance appraisal and its effect on the commitment and job skills of the teachers at university level. Journal of Socialomics, 5(3), 169179. http://doi.org/10.41 72/21670358.1000169

Ali, S., \& Fatima, F. (2016). Comparative Analysis of Safety and Security Measures in Public and Private Schools at Secondary Level. Journal of Socialomics, 5(3), 159-169. http://doi.org/10.41 72/21670358.1000169

Ali, S., Zamir, S., Fatima, F., \& Fatima, S. (2018). Comparative Analysis of Communication Climate and SelfEfficacy of Teachers at University Level. Journal of Management Sciences, 11(3), 186-212.

Ang, S.D., \& Huan, K. (2006). Choice theory: An investigation of the treatment effects of a choice theory assessing their students because every learner has its own learning capacity.

5. Higher authorities should have to design different seminars or workshops on depression and anxiety and advice the teachers to design easy content so that these problems may be screened out at an early stage.

\section{Source of Funding}

The authors declared no source of funding.

protocol on students identified as having a behavioral or emotional disability on measures of anxiety, depression, locus of control and selfesteem. Dissertation Abstracts International Section A: Humanities and Social Sciences, 72(8-A), 26692679.

Bashir, A. (2016). Role of depression in health profession Education. Medical Teacher, 56(5),67-78.

Busari, I., (2012). Faculty Perceptions of Mental Health Issues among College Students. Journal of College Student Development. 42(3),67-77.

Deb, S. (2015). Mental Health and WellBeing of University Students in Okinawa. Education Research International, 5(4),67-78.

Dobson, S. (2012). Frequency of depression, anxiety and stress among university students. Pakistan journal of medical sciences, 36(5), 971-976.

Fatima, F. (2014). Teachers' Attitude towards teamwork and its impact over research output of the teachers at University Level. Elixir International Journal, 75, 27292-27310.

Fatima, F. (2016). Comparative Analysis of National and International Approaches and Acuities of Child Labour Within UK, USA, India and 
Pakistan. American Journal of Educational Research, 4(18), 12711280. http://doi.org/ 10.12691/education-4-18-5

Fatima, F. (2017). Teachers attitude towards brain based learning and its effect on the achievement motivation of the students at university level. Science International (Lahore), 29(1), 315324.

Fatima, F. (2019). Teachers' Attitude towards teamwork at university level. Governance and Management Review (GMR), 4(1), 56-75.

Fatima, F., Ali, S. (2016). The Impact of Teachers' Financial Compensation on their Job Satisfaction at Higher Secondary Level. Journal of Socialomics 5(3), 164-174. http://doi.org/10.41 72/21670358.1000164

Fatima, F., \& Ali, S. (2019). Descriptive Analysis of Teachers' Perception about supportive and defensive communication climate along with their self-efficacy at University level. Governance and Management Review (GMR), 4(2), 56-74.

Fatima, F., \& Ali, S. (2020). Philosophical and Biological Foundation of Brain Based Learning: A Phenomenological Approach. International Journal of Innovation in Teaching and Learning (IJITL), 6(2), 1-19.

Fatima, F., Zamir, S., Ali, S., \& Fatima, S. (2018). Effect of Demographic Factors over the Achievement
Motivation of Students at university level in Islamabad. Journal of Managerial Sciences, 11(3), 213-236. Khanna,F.,\& Khanna,T.(1990). Scale of anxiety and depression in educational perspective. International Journal of Social Science, 4(5),56-67

Masih, B. \& Gulrez, J.M. (2006). The Relation of Depression and Anxiety to Life-Stress and Achievement in Students. British Journal of Psychology, 95 (4), 509-521.

Paul-Ratanasiripong, H.(2012). Anxiety and depression relationship in the context of education. Teacher Education, 67(3),67-78.

Reddy K. J, Menon K. R, Thattil A. (2018). Academic Stress and its Sources among University Students. Biomed Pharmacology Journal, 11(1), 45-67.

Shah, R. (2017). Cognitive Vulnerability Stress Theories of Depression: Examining Affective Specificity in the Prediction of Depression versus Anxiety in Three Prospective Studies. Cognitive Therapy and Research, 28 (3), 309-345.

Smith, J., Peterson, H., Degenhart, T., \& Johnson, B. (2007). Relationship between depression and anxiety in mental dis-order among children. American Journal of Educational Research, 7(5), 45-55.

Sohail N. (2013). Stress and academic performance among medical students. Journal of College of Physicians and Surgeons of Pakistan, 23 (1), 67-71. 